\title{
Population dynamics and phenology of two congeneric and sympatric lynx spiders Peucetia rubrolineata Keyserling, 1877 and Peucetia flava Keyserling, 1877 (Oxyopidae)
}

\author{
German Antonio Villanueva-Bonilla, Suyen Safuan-Naide \& João \\ Vasconcellos-Neto
}

To cite this article: German Antonio Villanueva-Bonilla, Suyen Safuan-Naide \& João Vasconcellos-Neto (2018) Population dynamics and phenology of two congeneric and sympatric lynx spiders Peucetia rubrolineata Keyserling, 1877 and Peucetia flava Keyserling, 1877 (Oxyopidae), Journal of Natural History, 52:5-6, 361-376, DOI: 10.1080/00222933.2018.1433339

To link to this article: https://doi.org/10.1080/00222933.2018.1433339

曲 Published online: 11 Feb 2018.

Submit your article to this journal $\sqsubset$

Щ Article views: 85

View Crossmark data $₫$ 


\title{
Population dynamics and phenology of two congeneric and sympatric lynx spiders Peucetia rubrolineata Keyserling, 1877 and Peucetia flava Keyserling, 1877 (Oxyopidae)
}

\author{
German Antonio Villanueva-Bonilla ${ }^{a}{ }^{a}$, Suyen Safuan-Naide ${ }^{b}$ \\ and João Vasconcellos-Netoc \\ aPós-Graduação em Biologia Animal, IB, UNICAMP, Campinas, Brazil; 'bepartamento de Zoologia, UNESP \\ -Campus de Botucatu, Botucatu, Brazil; 'Departamento de Biologia Animal, IB, UNICAMP, Campinas, Brazil
}

\begin{abstract}
Numerous phenological studies on spiders belonging to the families Oxyopidae, Thomisidae, Lycosidae, Selenopidae (e.g. Selenops cocheleti) and Salticidae (e.g. Psecas chapoda and Psecas viridipurpureus) have been conducted in the neotropical region. However, studies that simultaneously compare population dynamics and age structure in populations of sympatric species are limited, especially in Oxyopidae. The population dynamics and phenology of two congeneric lynx spider (Peucetia rubrolineata and Peucetia flava) were examined in southeastern Brazil. Several characteristics of the age structure were compared between the two spider species. The variation in the total abundance of individuals and age structure and their relationship with climatic variables were similar between the two spiders. Adults of these spiders were present mainly in spring, indicating an annual reproductive cycle and a 'stenochronous spring' phenological pattern. The recruitment of spiders occurred in summer for $P$. rubrolineata and $P$. flava, followed by successive phenological peaks at all stages of development. Rainfall and temperature had a positive correlation to population flux in the two spider species studied. Despite the significant climatic effects observed in the Serra do Japi, the phenological pattern of the population in this study was not always repeated in other species of spiders (e.g. Selenops cocheleti).
\end{abstract}

\section{ARTICLE HISTORY}

Received 18 April 2017

Accepted 22 January 2018

Online 12 February 2018

\section{KEYWORDS}

Age structures; Atlantic forest; seasonal patterns; Serra do Japi

\section{Introduction}

Population dynamics can be defined as the change in the number of individuals within a population in space and over time, and the understanding of the mechanisms that influence this change (Solomon 1980; Vargas and Rodriguez 2008). Several studies indicate that climatic factors, habitat structure and predation have the greatest influence on the stability of populations. In some species of birds, for example, changes in climate may have effects on reproductive success and adult survival (Wolf et al. 2009; Sandvik et al. 2012). In the tundra ecosystem, rodents are affected more by their habitat structure (configuration of willow bushes) than by climatic factors (Henden et al. 2011). Habitat also seems to be the most influential component in shaping the colonization and 
establishment of amphibians, and influences the increase or decrease in the number individuals within the population (Blaustein et al. 2011). On the other hand, predation was the primary cause of reduction of high densities of an aphid (Macrosiphum euphorbiae Thomas) that attacks greenhouse-grown roses (Rosa hybrida L.) by the predatory ladybird beetle Harmonia axyridis Pallas (Snyder et al. 2004). In the same way, predation was the principal mechanism of the decrease of the wooland caribou population in British Columbia, Canada (Wittmer et al. 2005).

In spiders, the availability and diversity of prey have been described as the critical factors driving population fluctuation (Turnbull 1966; Wise 1993). However, in wandering spiders, environmental factors have been shown to have a more considerable influence on the abundance of individuals than prey availability (Conley 1985; Rana et al. 2016; Villanueva-Bonilla and Vasconcellos-Neto 2016). For example, climatic variables can also affect the growth and development cycle of individuals (Vlijm and Kessler-Geschiere 1967) by altering the reproductive period (Rossa-Feres et al. 2000). Higher rainfall also is correlated with increased production of vegetative branches in the plant Trichogoniopsis adenantha (Asteraceae). Such dense branching consequently serves to attract herbivorous insects, which in turn leads to an increase in the population of the spider Misumenops argenteus Mello-Leitão, 1929 (Thomisidae) (Romero and Vasconcellos-Neto 2003). Habitat structure also plays an important role in regulating populations. A study on the Salticidae Psecas chapoda Peckham and Peckham, 1894 concluded that the flowering pattern and architecture of the plant Bromelia balansae (Bromeliaceae) influenced the population dynamics of the spider (Romero and Vasconcellos-Neto 2005a). In another example, the populations of Ctenus amphora Mello-Leitão, 1930 and Ctenus villasboasi Mello-Leitão, 1949 (Ctenidae) in fragmented habitats within the central Amazon region have been shown to be significantly smaller than what is observed in the continuous forest habitat (Rego et al. 2007).

The phenology of an organism is understood as the temporal variations in the life cycle of the individual (Menzel 2002; Romero and Vasconcellos-Neto 2003), and serves as an important aspect to understanding the population dynamics of a species (Wolda 1988). In spiders, the term phenology has been applied commonly to the study of variations in the age structure of populations (Romero and Vasconcellos-Neto 2003; Villanueva-Bonilla and Vasconcellos-Neto 2016) and to describe the life cycle of individuals (Nieto-Castañeda et al. 2012). Tretzel (1954) and Paquin and Dupérré (2001) argue that spiders may have four phenological patterns based on the reproductive period of the population as determined by the peak abundance of adult males. For example, the spider Selenops cocheleti Simon, 1880 (Selenopidae), which is commonly associated with trunks containing loose bark, presents a stenochronic summer phenological pattern - that is, the species has only one reproductive cycle throughout the year and adult males are present in greater abundance in summer (Villanueva-Bonilla and Vasconcellos-Neto 2016). Spiders can adjust their phenological patterns according to climatic conditions (Wise 1984). A study conducted on the west coast of Europe on three species of Lycosidae concluded that climate change and habitat were important factors in the phenological pattern observed in the populations. As such, the spider Pardosa monticola Clerck, 1757 presented a eurichronic pattern (several reproductive periods in a year), while Pardosa nigriceps Thorell, 1856 presented a diplochronic pattern (two reproductive periods in the year) and Pardosa pullata Clerck, 1757 a stenochronic 
pattern (a single reproductive period in the year) (Vlijm and Kessler-Geschiere 1967). Given these observations, in this paper the term phenology refers to temporal variation in the population structure and its phenological pattern to a better understanding of the dynamic of these populations (Romero and Vasconcellos-Neto 2005a).

Numerous phenological studies on spiders belonging to families Oxyopidae (e.g. Peucetia viridans, Arango et al. 2000; Peucetia flava, Morais-Filho \& Romero 2009), Thomisidae (e.g. Misumenops argenteus, Romero \& Vasconcellos-Neto 2003), Lycosidae (González et al. 2014), Selenopidae (e.g. Selenops cocheleti, Villanueva-Bonilla \& Vasconcellos-Neto 2016) and Salticidae (e.g. Psecas chapoda and Psecas viridipurpureus Simon, 1901, Rossa-Feres et al. 2000; Romero and Vasconcellos-Neto 2005a) have been conducted in the neotropical region, where the reproductive period of a population can vary from once in a year to populations where recruitment of individuals is constant and overlapping generations are observed (e.g. Romero and Vasconcellos-Neto 2005a; Ferreira et al. 2009). However, studies that simultaneously compare population dynamics and age structures in sympatric species populations are limited, especially in Oxyopidae. The Oxyopidae comprises 455 species within nine genera reported to date (World Spider Catalog 2017). They are non-weaver spiders associated with vegetation (Romero and Vasconcellos-Neto 2007; Vasconcellos-Neto et al. 2007; Morais-Filho and Romero 2009). The genus Peucetia is cosmopolitan and comprises 47 species, mostly occurring in tropical regions (Santos and Brescovit 2003; World Spider Catalog 2017). Most population studies were conducted on Peucetia viridans (e.g. Turner 1979; Randall 1982; Fink 1986; Nyffeler et al. 1987, 1992; Arango et al. 2000; Vasconcellos-Neto et al. 2007), with very little known about the population dynamics of other species of the genus Peucetia.

In southeastern Brazil, the congeneric spiders Peucetia rubrolineata Keyserling, 1877 and Peucetia flava Keyserling, 1877 are found almost exclusively associated with the plant T. adenantha (DC) (Asteraceae) (Vasconcellos-Neto and Romero 2012). Both species of spiders persist throughout the year although with different abundances depending on the weather and season. Studies comparing the age structure, population flux and other aspects of these sympatric congeneric species are almost non-existent. Only one study focused on the $P$. flava species inhabiting the Rhyncanthera dichotoma (Melastomataceae) plant; this study revealed that the ecosystem (marsh), climatic conditions and availability of prey varied reflecting the ecosystem studied (Morais-Filho and Romero 2009). Knowledge of population fluctuation as well as changes in age structure over time will help, for example, in the understanding of how sympatric congeneric species could persist and coexist if we expect strong competition by resources.

The objective of the present study was to: (1) describe the population dynamics of the two sympatric species $P$. rubrolineata and $P$. flava, and (2) to test the influence of climatic variables (temperature and precipitation) on the spider population dynamics.

\section{Materials and methods}

\section{Study area}

The Serra do Japi is located between $-23.231598 \mathrm{~S}$ and $-46.936784 \mathrm{~W}$, west of the Atlantic Plateau between the municipalities of Jundiaí, Itupeva, Cabreúva, Pirapora do Bom Jesus and Cajamar in the state of São Paulo, Brazil. Most of which is covered by 
seasonal mesophyll forest canopy. This area has an altitude ranging from $700 \mathrm{~m}$ to $1300 \mathrm{~m}$ above mean sea level. In the Serra do Japi the climate is stable with average monthly temperatures varying from $13.5^{\circ} \mathrm{C}$ in July to $20.3^{\circ} \mathrm{C}$ in January, with a rainy season in summer (December-March) and dry in winter (June-August) (Pinto 1992). The study was conducted from July 2013 to December 2015. Days of low precipitation and high temperature were recorded in 2014 (Figure 1).

\section{Population dynamics of Peucetia rubrolineata and Peucetia flava}

To determine variations in the number of individuals of $P$. rubrolineata, we sampled 100 plants of $T$. adenantha (Asteraceae) grown in a shaded area every month over the 2-year study period. The same procedure was followed to determine the variations in the number of individuals of $P$. flava. Given that the $P$. flava spider was rare and observed more in the sunny areas, our sample unit size was modified to 200 plants grown in an open area. Observations were collected along several tracks in areas located between altitudes of 950 and $1100 \mathrm{~m}$. For each inspected plant, we recorded the numbers of individual spiders as well as their stage of development and sex as adults. Later, circular statistics analysis was performed using the Rayleigh uniformity test to verify the population abundance peaks for the two species of spiders once the circular normality of the data was verified (Morellato et al. 2010).

\section{Phenology}

In the field, we tried to identify different size classes as an approach to different instars of Peucetia spiders. We identified eight size classes and photographed them with a scale in $\mathrm{mm}$ (Figure 2). These size classes were used in the categorization of the age structure of these spiders in the monthly counts. Size differentiation was based on the size of the cephalothorax and the femur of the first pair of legs of each individual observed in the field. We used these characteristics because they are quite distinct among instars. In the field, we used printed photographs of the different sizes classes for classification of the individuals observed. Later, to illustrate the age structure of the two populations of Peucetia, we grouped the spiders' instars into five categories as described by Romero

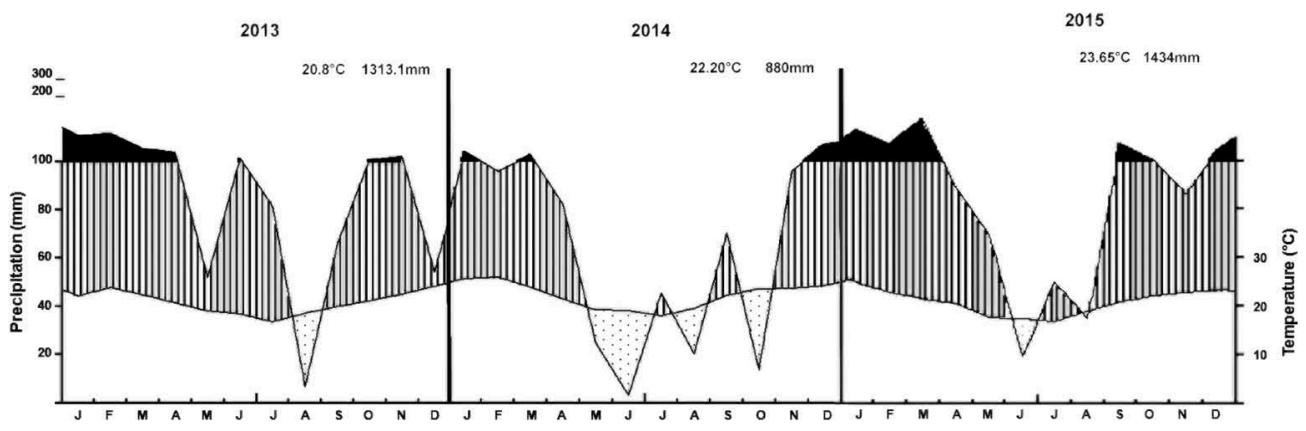

Figure 1. Climatic diagram of the Serra do Japi, SP, Brazil, based on the climatic data collected from the Jundiaí experimental station. Areas in black indicate very humid periods. Areas with vertical lines indicate humid periods. Dotted areas indicate dry periods. 

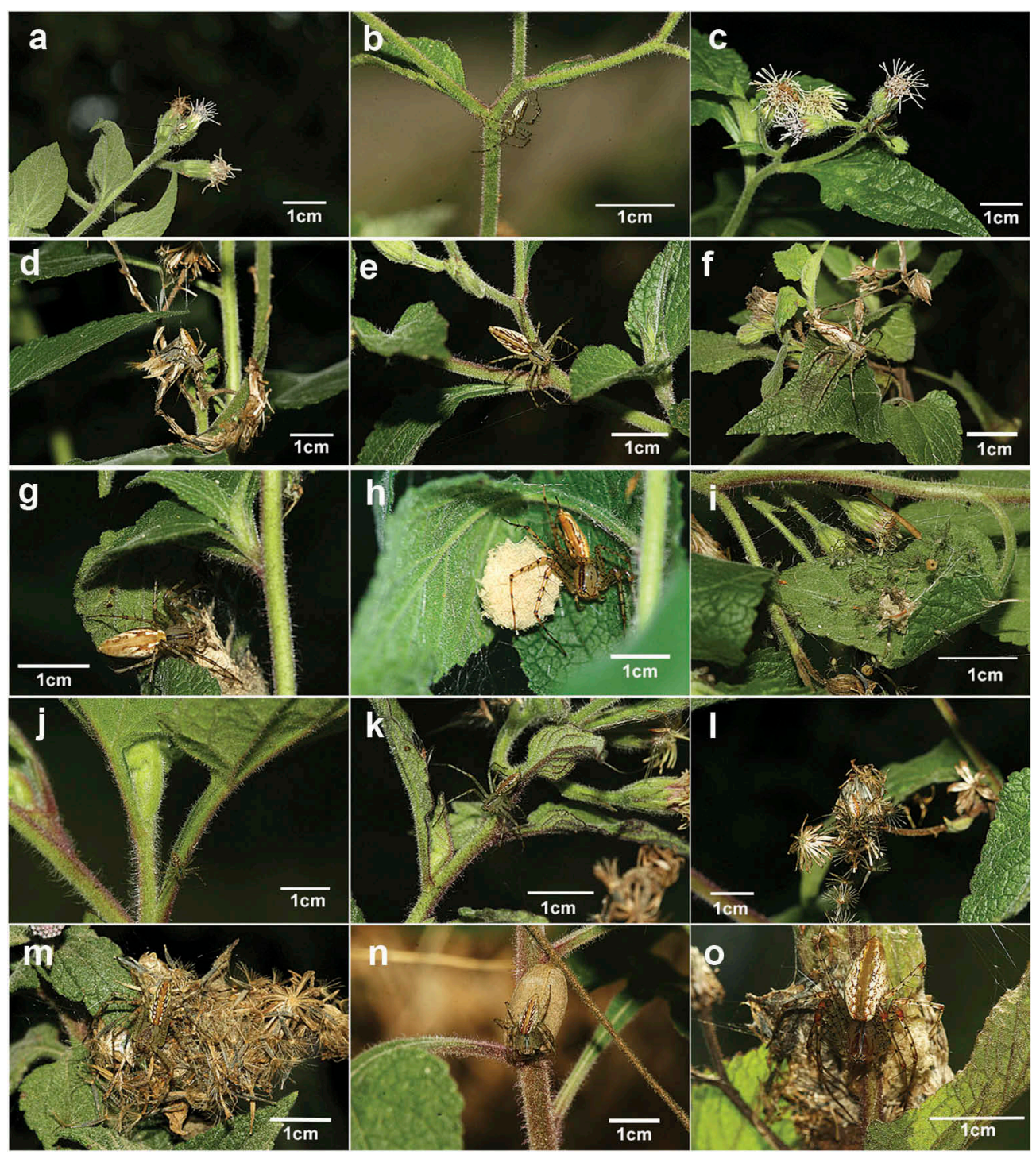

Figure 2. Instars of Peucetia rubrolineata (a-h) and Peucetia flava ( $\mathrm{i}-\mathrm{o})$ (Oxyopidae) recorded in the Trichogoniopsis adenantha (Asteraceae) plant in the Serra do Japi, SP, Brazil. (a, i) second instar; (b, j) third instar; (c, k) fourth instar; (d, l) fifth instar; (e, m) sixth instar; $(f, n)$ seventh instar (subadult); ( $g, h, n)$ eighth instar (adult).

and Vasconcellos-Neto (2005a): Newly emerged (spiderling spiders = second instar); Young spiders (third and fourth); Juveniles (fifth and sixth instar), males and females subadults (seventh instar) and adult males and females (eighth instar).

\section{Synchrony between events}

To verify whether the variations in the number of individuals of $P$. rubrolineata and $P$. flava were related to the macro-climate pattern of Serra do Japi (variations in precipitation and 
temperature), we employed the Spearman correlation test after testing for normality of the data using the Shapiro-Wilk test. To test whether events occurred synchronously, we applied correlation tests with temporal lags of up to 3 months (see Sokal and Rohlf 1994; Zar 1998; Romero and Vasconcellos-Neto 2003). Precipitation and temperature data were obtained from the Jundiaí Experimental Station (ETECJ), which is located approximately $8 \mathrm{~km}$ from the study area. Temperature data were adjusted to the study area by subtracting $0.6^{\circ} \mathrm{C}$ per $100 \mathrm{~m}$ elevation (Whiteman 2000).

\section{Results}

\section{Population dynamics}

The population fluctuation over the course of this study was similar in the two species of spiders (Figure 3), differing only in their densities on the plant. The mean number of individuals per month of Peucetia rubrolineata was $24.2 \pm 18.13$, ranging from 61 individuals in January 2015 to zero individuals recorded in September 2013. During the period of high spider abundance at the 100 plants sampled, only 44 (44\%) plants had at least one spider and at times the same plant contained up to four spiders. On the other hand, for $P$. flava, the average number of spiders per month was $20.93 \pm 12.38$, ranging from 41 individuals in June 2014 to 4 individuals in September of the same year. During the period of high spider abundance, of the 200 plants sampled only 29 (15.5\%) had at least one spider and at times the same plant contained up to six spiders. The distribution of the two species was uneven throughout the year with a peak in abundance in March for P. rubrolineata (Rayleigh Test: $z=67.46 ; p=<0.0001$; Tables 1 and 2; Figure 4) and in April for P. flava (Rayleigh Test: $z=23.02 ; p=<0.0001$; Tables 1 and 2; Figure 4). The two populations had an increase in the number of individuals at the beginning of summer (moist season) but their population declined by mid-autumn (Figure 3).

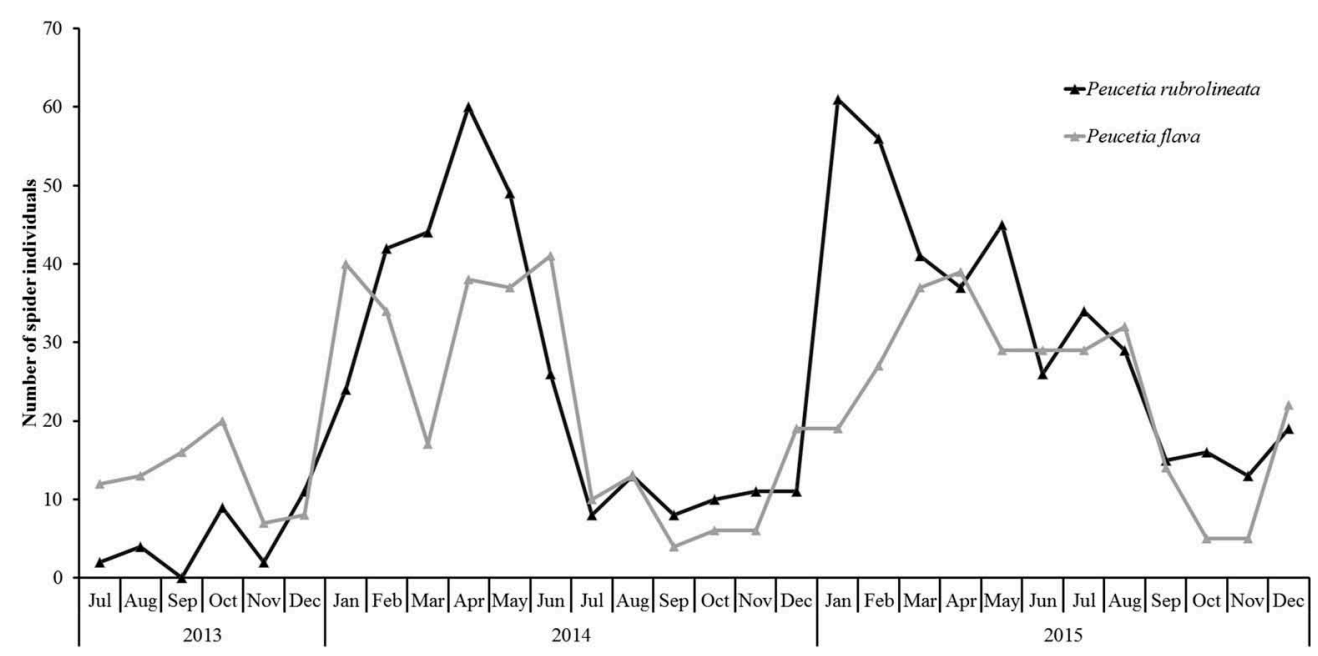

Figure 3. Population fluctuation of Peucetia rubrolineata and Peucetia flava (Oxyopidae) in 100 and 200 plants, respectively, of Trichogoniopsis adenantha (Asteraceae). 


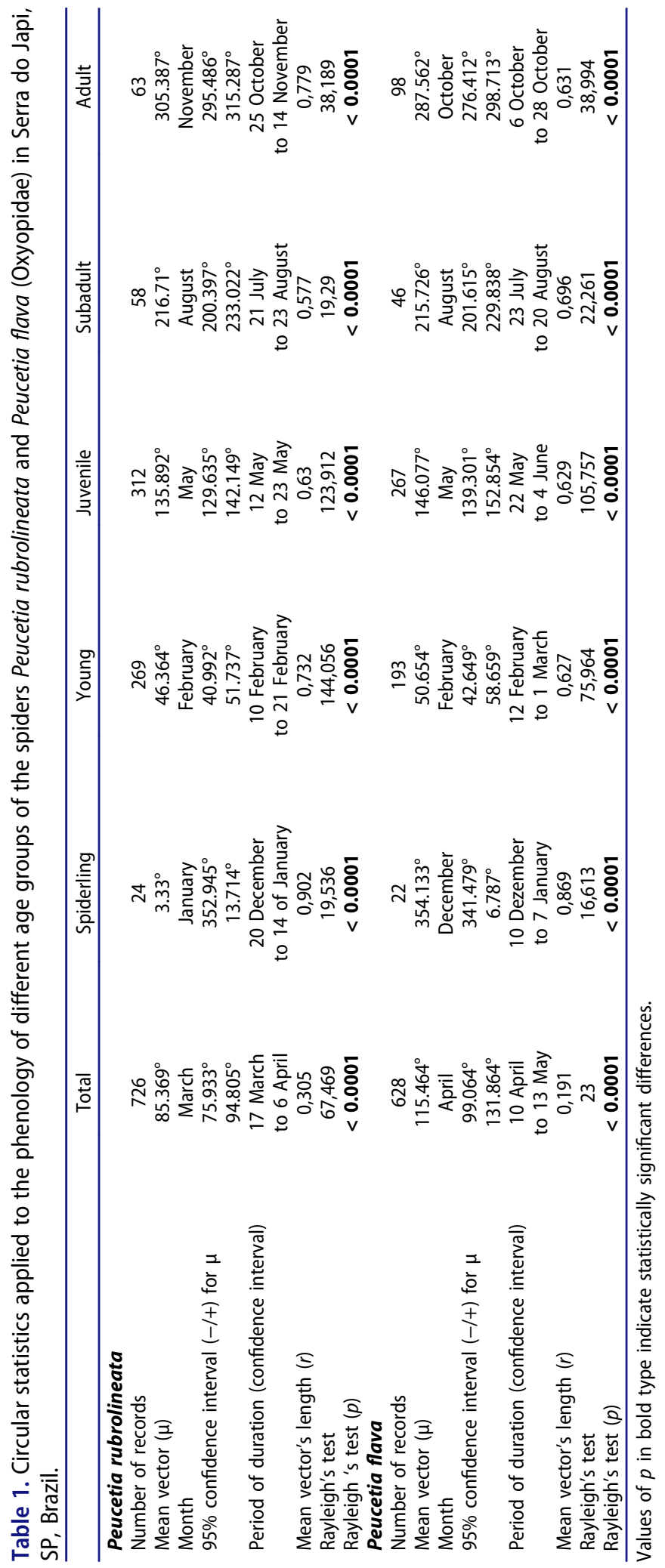


Table 2. Spearman's correlation coefficient between the abundance of Peucetia rubrolineata and Peucetia flava with environmental factors (rainfall and temperature), with up to 3 months of time lag on the dependent variable. Serra do Japi, SP, Brazil.

\begin{tabular}{lccc}
\hline & Time-lag (months) & $R$ & $p$ (value) \\
\hline Raifall vs abundance of $P$. rubrolineata & 0 & 0.287 & 0.1738 \\
& 1 & 0.584 & 0.0034 \\
Temperature vs abundance of $P$. rubrolineata & $\mathbf{2}$ & $\mathbf{0 . 6 3 5}$ & $\mathbf{0 . 0 0 1 5}$ \\
& 3 & 0.460 & 0.0361 \\
& 0 & 0.346 & 0.0974 \\
Rainfall vs abundance of $P$. flava & 1 & 0.647 & 0.0008 \\
& $\mathbf{2}$ & $\mathbf{0 . 8 3 2}$ & $\mathbf{0 . 0 0 0 1}$ \\
& 3 & 0.806 & 0.0001 \\
Temperature vs abundance of $P$. flava & 0 & 0.119 & 0.5795 \\
& 1 & 0.337 & 0.1161 \\
& 2 & 0.504 & 0.0167 \\
& $\mathbf{3}$ & $\mathbf{0 . 8 2 9}$ & $\mathbf{0 . 0 0 0 1}$ \\
& 0 & 0.007 & 0.9742 \\
& 1 & 0.309 & 0.1504 \\
\end{tabular}

Values in bold type indicate significant differences.

\section{Total abundance}

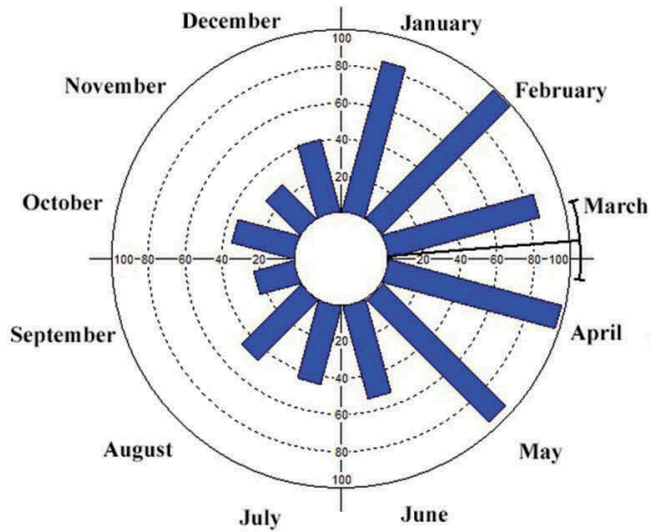

\section{Total abundance}

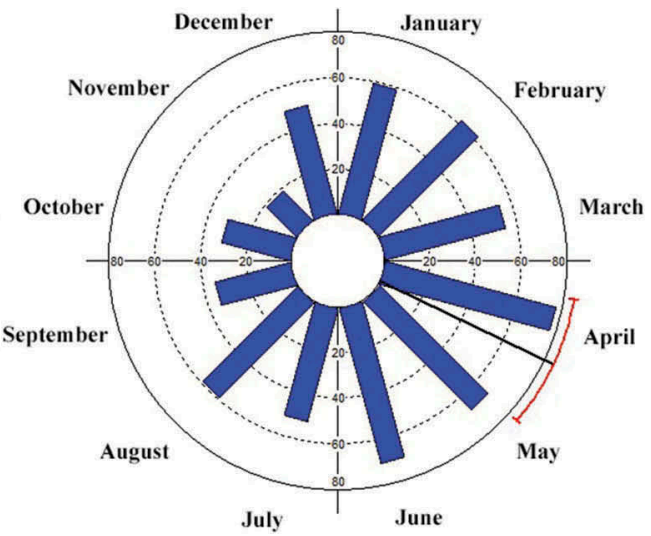

Figure 4. Circular histogram of the abundance of the two spider populations: right, Peucetia rubrolineata; left, Peucetia flava, from July 2013 to December 2015 in Serra do Japi, SP, Brazil. The black line outside the circle indicates the average angle or direction of the data. The transverse line on the outside of the circle indicates the $95 \%$ confidence interval.

\section{Phenology}

The phenological pattern of the two species was similar as they had similar distribution in age structure over the study period. The similarity is revealed by the peak of adult abundance (breeding period) in spring followed by the deposition of the egg-sacs, the emergence of spiderlings in summer, young and juveniles in late summer and autumn, and subadults in winter. This cycle repeated with the appearance of adult individuals in the following spring (Figures 5 and 6).

All age classes of both spider species showed marked peaks of abundance during different months of the year. The peaks for the same age class were observed during the 


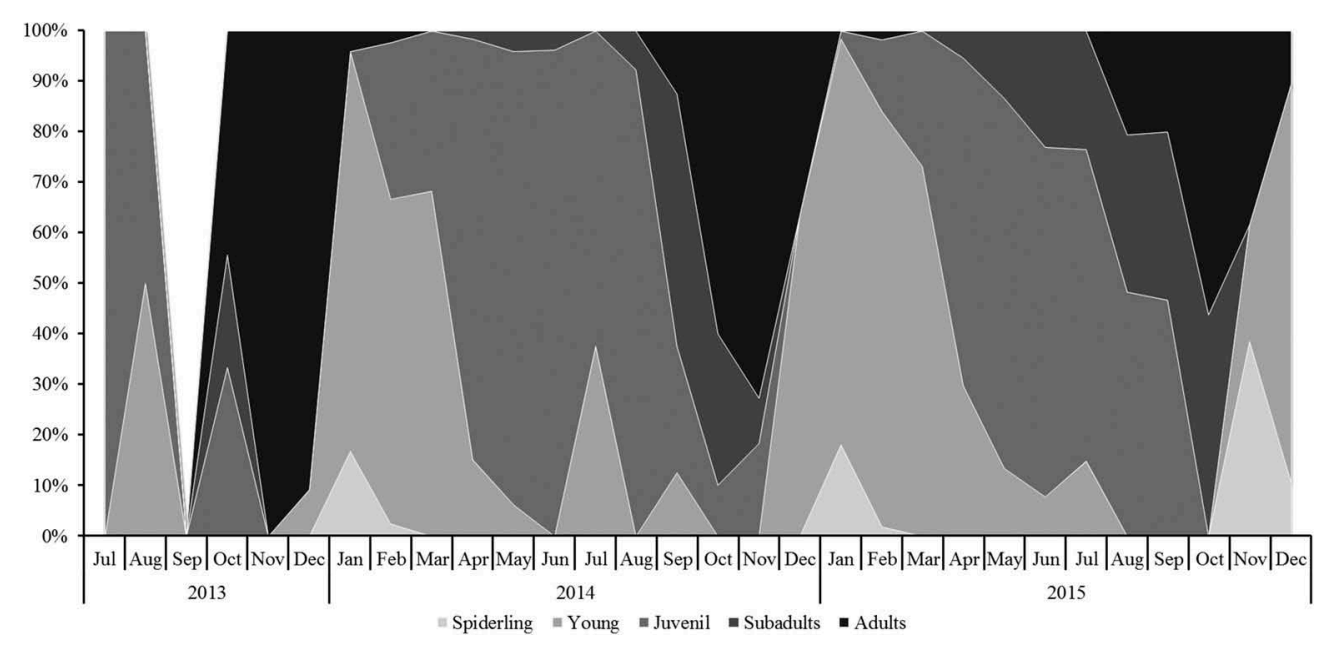

Figure 5. Phenogram of the population of Peucetia rubrolineata (Oxyopidae) on Trichogoniopsis adenantha (Asteraceae, $n=100$ ) between July 2013 and December 2015, Serra do Japi, SP, Brazil.

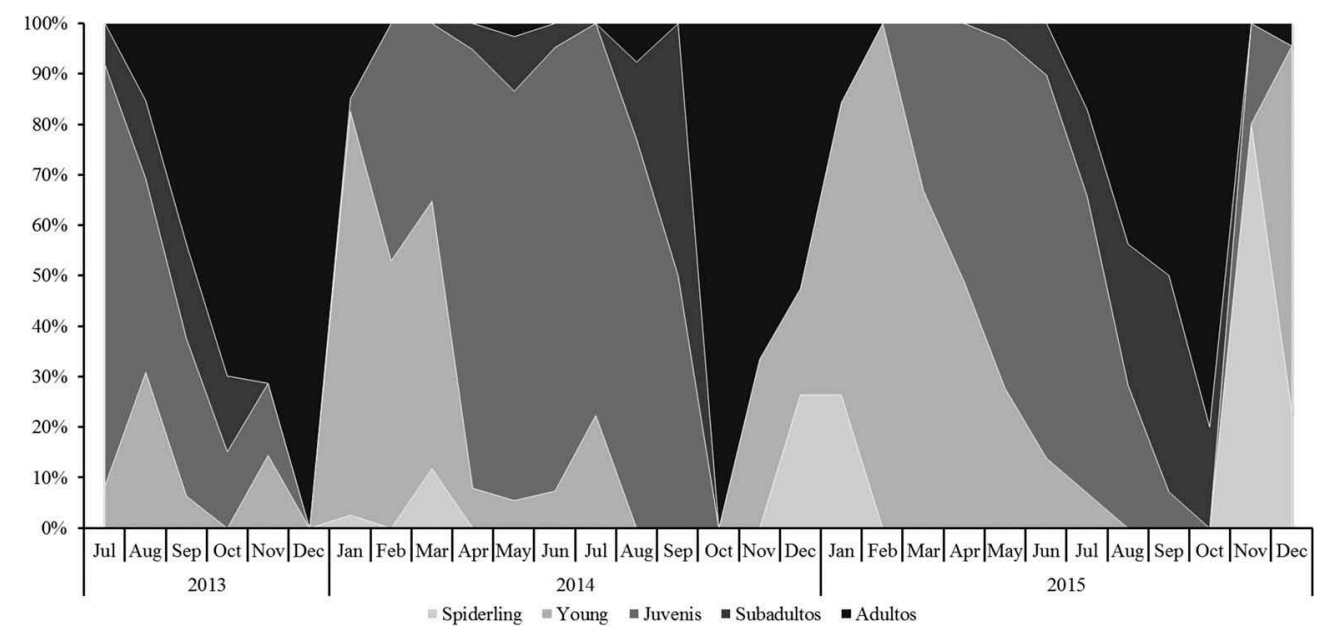

Figure 6. Phenogram of the population of Peucetia flava (Oxyopidae) on plants of Trichogoniopsis adenantha (Asteraceae, $n=200$ ) between July 2013 and December 2015, Serra do Japi, SP, Brazil.

same season (Figures 7 and 8; Table 1). These data indicate that the life cycles of these two species do not differ significantly.

The two populations showed a stenochronic phenological pattern in spring, i.e. was typically a single reproductive period season each year, occurring in the spring. This is shown by the marked peak in adult reproductive period in both species of spiders during spring (Figures 7 and 8; Table 1). However, data reveal that even though their reproductive periods were not synchronized, there was considerable overlap between them. In $P$. rubrolineata the reproductive period occurred during November, while the reproductive period of $P$. flava began a month earlier in October. 
Spiderlings

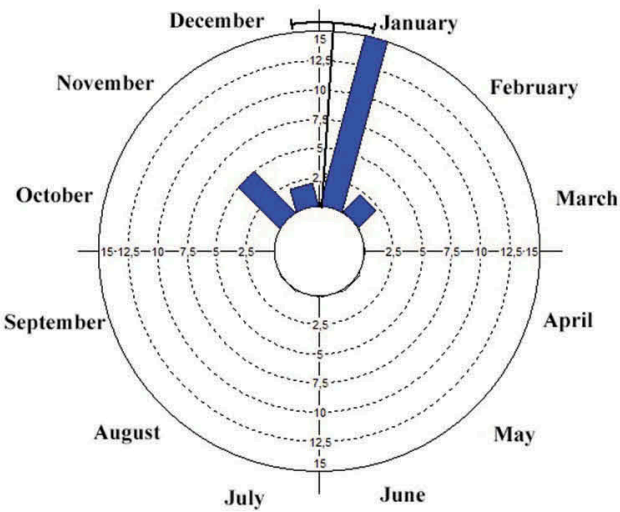

Juveniles

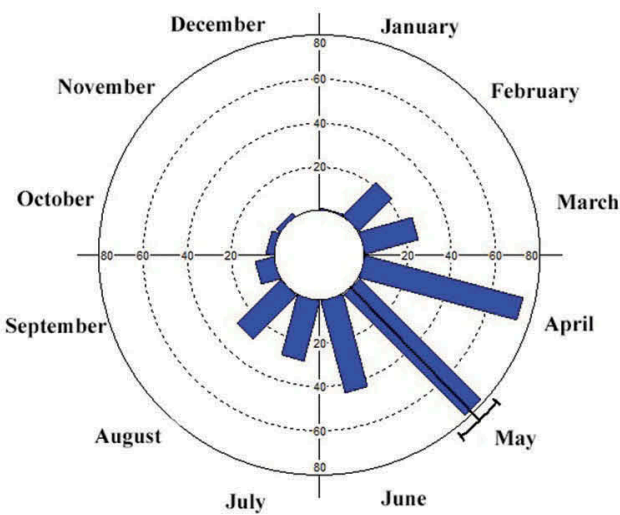

Adults

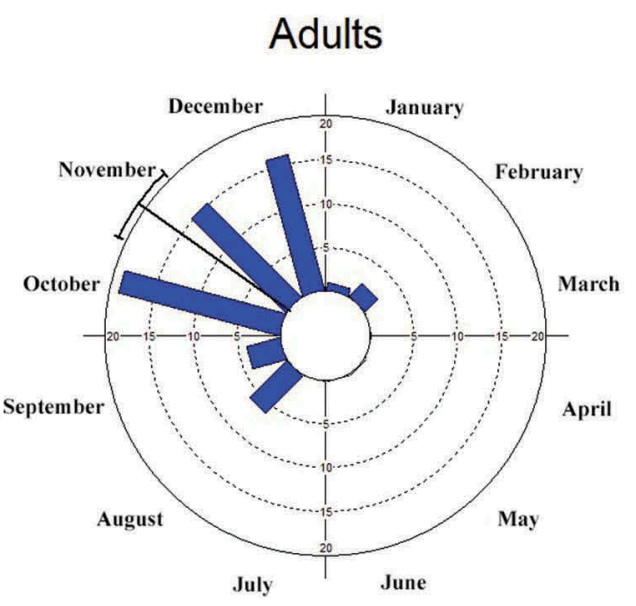

Young

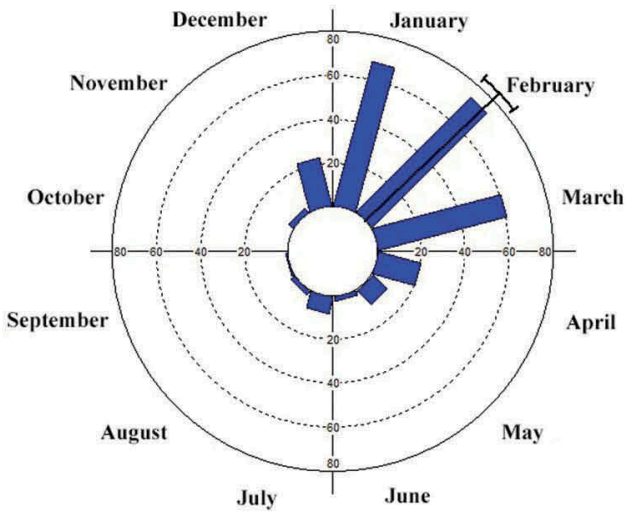

Subadults

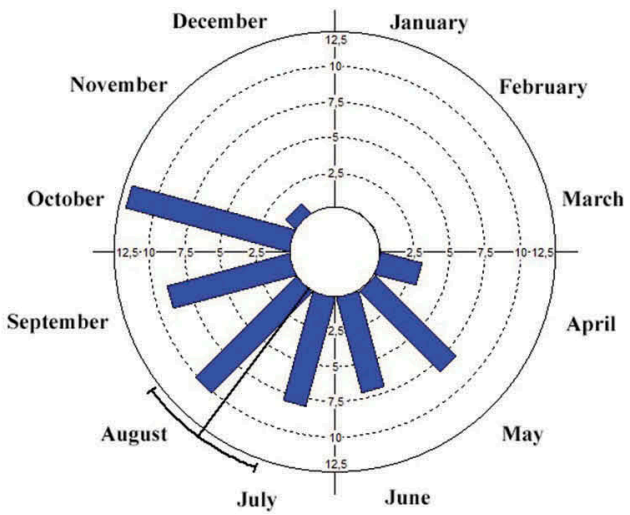

Figure 7. Circular histograms of the frequency of age structure established for the population of Peucetia rubrolineata (Oxyopidae) from July 2013 to December 2015 in Serra do Japi, SP, Brazil. The black line vector inside the circle indicates the angular mean or direction of the data. The transverse line in the sector outside the circle indicates the 95\% confidence interval. 


\section{Spiderlings}

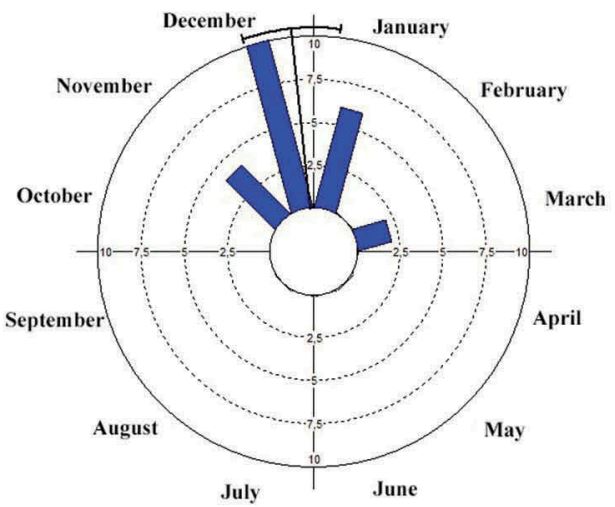

Juveniles

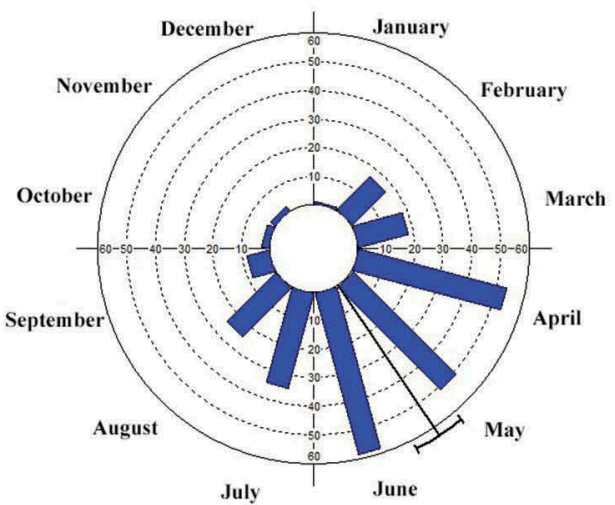

Adults

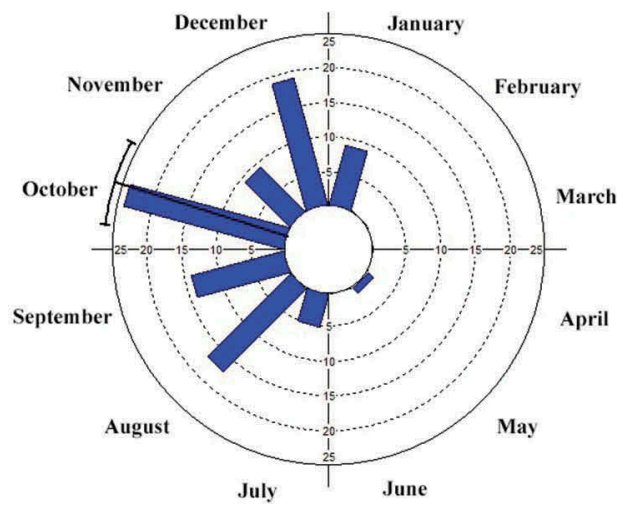

Young

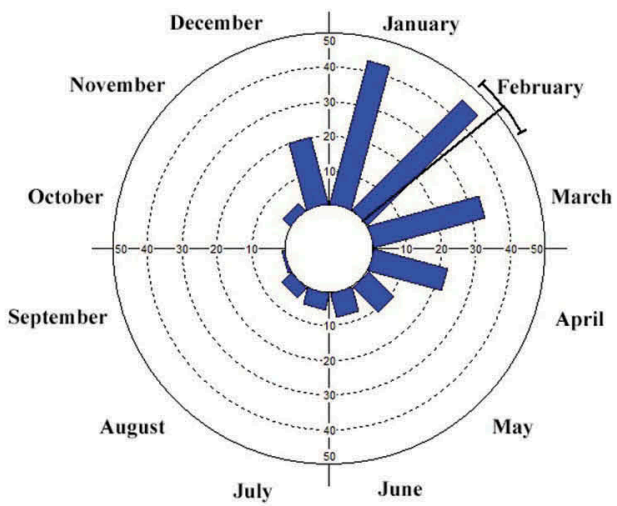

Subadults

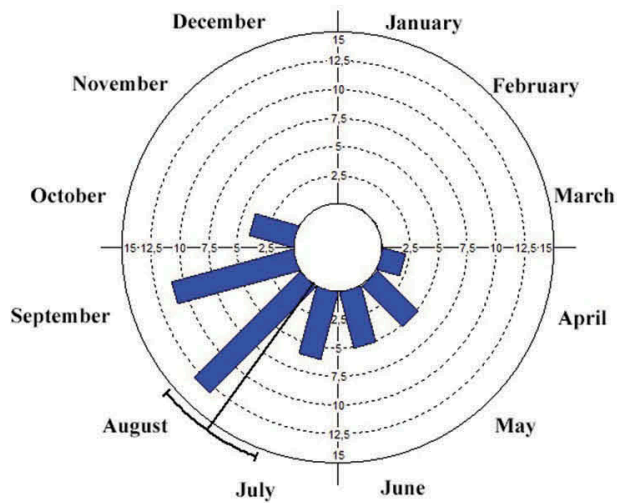

Figure 8. Circular histograms of the frequency of the age structure established for the population of Peucetia flava (Oxyopidae) from July 2013 to December 2015 in Serra do Japi, SP, Brazil. The black line vector inside the circle indicates the angular mean or direction of the data. The transverse line in the sector outside the circle indicates the $95 \%$ confidence interval. 


\section{Synchrony due to natural events}

Abundance of $P$. rubrolineata and $P$. flava individuals was directly correlated with rainfall and temperature. However, the events did not occur synchronously, with time lags of 2 and 3 months, respectively (Table 2 ).

\section{Discussion}

Our observations indicate that the populations of $P$. rubrolineata and $P$. flava present a stenochronic pattern in spring with a very marked period of adult spider activity at a defined time in the year - according to the classifications of Tretzel (1954) and Paquin and Dupérré (2001). Our study suggests that both $P$. rubrolineata and $P$. flava present a single reproductive period in the spring followed by the deposition of eggs and recruitment of new individuals in summer (January-December). Subsequently, the juveniles (fifth and sixth instars) appear mainly in autumn and winter when temperatures and precipitation are low. From a developmental point of view, this phase is longer, probably due to limited availability of prey. During the dry year 2014 this effect was exacerbated in the age structure of both $P$. rubrolineata and $P$. flava. Morais-Filho and Romero (2009) reported contrasting results in a different location, wherein $P$. flava revealed seasonal stability and overlapping generations resulting from consistent fecundity throughout the year. On the other hand, populations of Misumenops argenteus, Eustala taquara and Eustala perfida revealed phenological patterns similar to the two Peucetia species studied (Romero and Vasconcellos-Neto 2003; Souza 2013). In these studies conducted at the Serra do Japi, all species had similar age structures with successive peaks of the developmental stages of spiders appearing throughout the year.

Climatic variables were the most important factors influencing the age structure of $P$. rubrolineata and $P$. flava populations. We observed a positive correlation between rainfall and temperature and the abundance of both species. It is known that summer (when temperature and rainfall are usually higher) shows an increase in insect and arthropod populations (Wolda 1988; Tidon 2006; Pereira da Silva et al. 2011; Kishimoto-Yamada and Itioka 2015), thereby increasing prey availability for the spiders. Romero and Vasconcellos-Neto (2005b) reported the presence of several types of insects on $T$. adenantha between November and January (summer). These results indicate strong bottom-up effects since, with increasing rainfall, the increase in the insect populations on $T$. adenantha plants should, in our view, positively affect the abundance of the two spider species. Another population study conducted in Yucatan, Mexico on the spider $P$. viridans also revealed similar relationships between precipitation and population. In the Yucatan study, $P$. viridans also presented a time lag; in other words, an increase in the number of individuals was observed a few months after rainfall and prey availability changed (Arango et al. 2000). Since the study was not conducted for the whole year, it is not possible to infer the population levels of $P$. viridans during the initial few months in the year. Studies with other spiders also demonstrate strong effects of climatic variables on population fluctuation. For example, in a plant-spider system (plant T. adenantha and spider Misumenops argenteus), bottom-up effects were also observed, wherein the increase in precipitation positively affected the productivity of vegetative 
branches, which increased the number of arthropods associated with this plant and benefited the spider population (Romero and Vasconcellos-Neto 2003).

A study performed on social spiders in the Serra do Japi also reported seasonal patterns of populations. Marques et al. (1998) recorded similar life cycle patterns in two sympatric species Anelosimus jabaquara and Anelosimus dubiosus (Theridiidae). These species also presented marked peaks of adults in late spring and during early summer, which points to a single reproductive period in these species. These authors also recorded developmental stages and found that the reproductive period of A. jabaquara occurred in December whereas for $A$. dubiosus it occurred in November. The short reproductive period windows observed in $P$. rubrolineata and $P$. flava could therefore, diminish the competition between emerging spiderlings and facilitate coexistence of congeneric sympatric species. However, this has not been tested in the field and other resource partitioning mechanisms may contribute to the coexistence of the two species studied (e.g. differential use of micro-habitat, different diet). Additionally, in the field no predation events were observed among the species studied. Furthermore, in very few instances the two spider species were recorded on the same plant (personal observation).

Despite the significant climatic effects observed in the Serra do Japi, the population profile observed in this study was not always repeated in other species of spiders. The bark-dwelling spider Selenops cocheleti (Selenopidae) maintains stable population composition throughout the year (Villanueva-Bonilla and Vasconcellos-Neto 2016). Because this selenopid maintains a stable population level it is possible that some generations overlap. Such overlapping generations and the continued availability of adult females results in constant oviposition and reproduction and, consequently, constant recruitment of individuals.

In summary, we report that the population fluctuation and age structure of $P$. rubrolineata and $P$. flava inhabiting $T$. adenantha were similar. Ecologically similar populations share resources diligently to reduce or avoid competition (Hutchinson 1957). If these two spiders have similar ecological timescales, i.e. if both have similar abundance peaks occurring in identical climatic stations throughout the year, then the interspecific competition could be intense. However, from our study it appears that different feeding strategies and/or preference to occupy specific microhabitats within the host plant may favour the coexistence of these two congeneric species.

\section{Acknowledgements}

We thank the Prefeitura Municipal de Jundiaí, SP, Brazil for granting permission to work at the Biological Reserve of the Serra do Japi. The authors also thank Instituto de Estudos dos Himenóptera Parasitóides da Região Sudeste Brasileira (INCT HYMPAR - SUDESTE-CNPq, FAPESP, CAPES), Yuri Fanchini Messas, Hebert Silva e Souza and anonymous reviewers for helpful comments on the manuscript.

\section{Disclosure statement}

No potential conflict of interest was reported by the authors. 


\section{ORCID}

German Antonio Villanueva-Bonilla (1) http://orcid.org/0000-0002-9599-8496

\section{References}

Arango AM, Rico-Gray V, Parra-Tabla V. 2000. Population structure, seasonality and habitat use by the green lynxs spider, Peucetia viridians (Oxyopidae) inhabiting Cnidoscolus aconitifolius (Euphorbiaceae). J Arachnol. 28(2):185-194.

Blaustein AR, Han BA, Relyea RA, Johnson PT, Buck JC, Gervasi SS, Kats LB. 2011. The complexity of amphibian population declines: understanding the role of cofactors in driving amphibian losses. Ann NY Acad Sci. 1223(1):108-119.

Clerck C. 1757. Svenska spindlar, uti sina hufvud-slågter indelte samt under några och sextio särskildte arter beskrefne och med illuminerade figurer uplyste. Stockholmiae, 154 pp.

Conley MR. 1985. Predation versus resource limitation in survival of adult burrowing wolf spiders (Araneae: Lycosidae). Oecologia. 67:71-75.

Ferreira RL, Prous X, Machado SF, Martins RP. 2009. Population dynamics of Loxosceles similis (Moenkhaus, 1898) in a brazilian dry cave: a new method for evaluation of population size. Ver. Bras Zoociências. 7(1):129-141.

Fink LS. 1986. Costs and benefits of maternal behaviour in the green lynx spider (Oxyopidae, Peucetia viridans). Animal Behaviour. 34(4):1051-1060.

González M, Costa FG, Peretti AV. 2014. Strong phenological differences between two populations of a Neotropical funnel-web wolf spider. J. Nat Hist. 48(35-36):2183-2197.

Henden JA, Ims RA, Yoccoz NG, Sørensen R, Killengreen ST. 2011. Population dynamics of tundra voles in relation to configuration of willow thickets in southern arctic tundra. Polar Biol. 34 (4):533-540.

Hutchinson GE. 1957. Concluding remarks. Cold Spring Harbor Symposia on Quantitative Biology. 22:415-427.

Kishimoto-Yamada K, Itioka T. 2015. How much have we learned about seasonality in tropical insect abundance since Wolda (1988)? Entomol Sci. 18:407-419.

Marques ESA, Vasconcellos-Neto J, de Mello MB. 1998. Life History and Social Behavior of Anelosimus jabaquara and Anelosimus dubiosus (Araneae, Theridiidae). J Arachnol. 26:227-237.

Mello-Leitão CF de. 1949. Aranhas da Foz do Koluene. Boletim do Museu Nacional do Rio de Janeiro (N.S., Zool.) 92:1-19, 14 pls.

Menzel A. 2002. Phenology: its importance to the global change community. An editorial comment. Clim Change. 54:379-385.

Morais-Filho JC, Romero GQ. 2009. Natural history of Peucetia flava (Araneae, Oxyopidae): seasonal density fluctuation, phenology and sex ratio on the glandular plant Rhyncanthera dichotoma (Melastomataceae). J Nat Hist. 43:701-711.

Morellato LPC, Alberti LF, Hudson IL. 2010. Applications of circular statistics in plant phenology: a case studies approach. In: Hudson IL, Keatley M, editors. Phenological research: methods for environmental and climate change analysis. Netherlands: Springer; p. 357-371.

Nieto-Castañeda IG, Salgado-Ugarte SH, Jiménez-Jiménez ML. 2012. The life cycle of a desert spider inferred from observed size frequency distribution. Acta Zool Mex (NS). 28(2):353-364.

Nyffeler M, Dean DA, Sterling WL. 1987. Predation by green lynx spider, Peucetia viridans (Araneae: Oxyopidae), inhabiting cotton and woolly croton plants in east Texas. Environ Entomol. 16:355-359.

Nyffeler M, Dean DA, Sterling WL. 1992. Diets, feeding specialization, and predatory role of two lynx spiders, Oxyopes salticus and Peucetia viridans (Araneae: Oxyopidae), in a Texas cotton agroecosystem. Environ Entomol. 21:1457-1465.

Paquin P, Dupérré N. 2001. On the distribution and phenology of Argyrodes fictilium (Araneae, Theridiidae) at its northern limit of North America. J Arachnol. 29(2):238-243.

Peckham GW, Peckham EG. 1894. Spiders of the Marptusa group. Occasional Papers of the Natural History Society of Wisconsin. 2:85-156. 
Pereira da Silva NA, Frizzas MR, de Oliveira CM. 2011. Seasonality in insect abundance in the "Cerrado" of Goiás State, Brazil. Rev Bras Entomol. 55:79-87.

Pinto HS. 1992. Clima da Serra do Japi, Campinas: UNICAMP/FAPESP. In: Morellato LPC, editor. História Natural da Serra do Japi: Ecologia e Preservação de uma Área Florestal no Sudeste do Brasil. Campinas: UNICAMP/FAPESP. p. 30-38.

Rana MA, Shabnam M, Rana N, Sultana T, Sultana S, Kanwal S, Ahmad I. 2016. Population dynamics of ground dwelling spider genera among mustard crop. J Biodivers Environ Sci. 8(2):114-123.

Randall JB. 1982. Prey records of the green lynx spider, Peucetia viridans (Hentz) (Araneae: Oxyopidae). J Arachnol. 10:19-22.

Rego FNAA, Venticique EM, Brescovit AD. 2007. Effects of forest fragmentation on four Ctenus spider populations (Araneae: Ctenidae) in central Amazonia, Brazil. Stud Neotrop Fauna Environ. 42(2):137-144.

Romero GQ, Vasconcellos-Neto J. 2003. Natural History of Misumenops argenteus (Thomisidae): seasonality and Diet on Trichogoniopsis adenantha (Asteraceae). J Arachnol. 31:297-304.

Romero GQ, Vasconcellos-Neto J. 2005a. Population dynamics, age structure and sex ratio of the bromeliaddwelling jumping spider, Psecas chapoda (Salticidae). J Nat Hist. 39(2):153-163.

Romero GQ, Vasconcellos-Neto J. 2005b. Flowering phenology, seed set and arthropod guilds in Trichogoniopsis adenantha (DC) (Asteraceae) in south-east Brazil. Rev Bras Bot. 28(1):171-178.

Romero GQ, Vasconcellos-Neto J. 2007. Aranhas sobre plantas: dos comportamentos de forrageamento às associações específicas. In: Gonzaga MO, Santos AJ, Japyassú HF, editors. Ecologia e comportamento de aranhas. Rio de Janeiro: Interciência; p. 66-87.

Rossa-Feres DDC, Romero GQ, Gonçalves-de-Freitas E, Feres RJF. 2000. Reproductive behavior and seasonal occurrence of Psecas viridipurpureus (Salticidae, Araneae). Rev Bras Biol. 60(2):221-228.

Sandvik H, Erikstad E, Sæther BE. 2012. Climate affects seabird population dynamics both via reproduction and adult survival. Mar Ecol-Prog Ser. 454:273-284.

Santos AJ, Brescovit AD. 2003. A revision of the Neotropical species of the lynx spider genus Peucetia Thorell 1869 (Araneae: Oxyopidae). Insect Syst Evol. 34:95-116.

Simon E. 1880. Révision de la famille des Sparassidae (Arachnides). Actes de la Société Linnéenne de Bordeaux 34:223-351.

Snyder WE, Ballard SN, Yang S, Clevenger GM, Miller TD, Ahn JJ, Berryman AA. 2004. Complementary biocontrol of aphids by the ladybird beetle Harmonia axyridis and the parasitoid Aphelinus asychis on greenhouse roses. Biol Control. 30(2):229-235.

Sokal RR, Rohlf FJ. 1994. Biometry: the principles and practice of statistics in biological research. New York: W. H. Freeman and Company.

Solomon ME. 1980. Dinâmica de populações São Paulo (Brasil). São Paulo: Editora Pedagógica e Universitária Ltda-EPU.

Souza HS (2013) Biologia e Ecologia de Eustala Taquara (Keyserling, 1892) (Araneae, Araneidae) na Serra do Japi, Jundiaí - SP, Brasil. [Master degree dissertation]. Campinas (SP): Universidade Estadual de Campinas.

Thorell T. 1856. Recensio critica aranearum suecicarum quas descripserunt Clerckius, Linnaeus, de Geerus. Nova Acta Regiae Societatis Scientiarum Upsaliensis (3) 2(1): 61-176.

Tidon R. 2006. Relationships between drosophilids (Diptera,Drosophilidae) and the environment in two contrasting tropical vegetations. Biol J Linn Soc. 87:233-247.

Tretzel EV. 1954. Reife- und Fortpflanzungszeit bei Spinnen. Z Morph Ökol Tiere. 42:634-691.

Turnbull AL. 1966. A population of spiders and their potential prey in an overgrazed pasture in eastern Ontario. Can J Zool. 44:557-583.

Turner M. 1979. Diet and feeding phenology of the Green Lynx Spider, Peucetia viridans (Araneae: Oxyopidae). J Arachnol. 7:149-154.

Vargas R, Rodriguez S. 2008. Dinámica de poblaciones. In: Ripa R, Larral P, editors. Manejo de plagas en paltos y cítricos. Instituto de Investigaciones Agropecuarias, INIA, Ministerio de Agricultura. Chile: Centro Regional de Investigación La Cruz; p. 99-101.

Vasconcellos-Neto J, Romero GQ, Santos AJ, Dippenaar-Schoeman AS. 2007. Associations of spiders of the genus Peucetia (Oxyopidae) with plants bearing glandular hairs. Biotropica. 39:221-226. 
Vasconcellos-Neto J, Romero GQ. 2012. Interações bióticas entre Trichogoniopsis adenantha (Asteraceae) e artrópodes na Serra do Japi, Jundiaí-SP. Curitiba: Editora CRV. In: VasconcellosNeto J, Polli PR, Penteado-Dias AM, Orgs. Novos Olhares, Novos Saberes Sobre a Serra do Japi. Curitiba: Ecos de sua biodiversidade; p. 251-271.

Villanueva-Bonilla GA, Vasconcellos-Neto J. 2016. Population dynamics and phenology of the wall crab spider Selenops cocheleti Simon, 1880 (Araneae: Selenopidae) in Southeastern Brazil. Stud Neotrop Fauna Environ. 51(3):215-230.

Vlijm L, Kessler-Geschiere AM. 1967. The Phenology and Habitat of Pardosa monticola, P. nigriceps and $P$. pullata (Araneae, Lycosidae). J Anim Ecol. 36:31-56.

Whiteman CD. 2000. Mountain meteorology: fundamentals and applications. Oxford, UK: Oxford University Press.

Wise DH. 1984. Phenology and life history of the filmy dome spider (Araneae: Linyphiidae) in two local Maryland populations. Psyche. 91(3-4):267-288.

Wise DH. 1993. Spiders in ecological webs. Cambridge: Cambridge University Press.

Wittmer HU, Sinclair AR, McLellan BN. 2005. The role of predation in the decline and extirpation of woodland caribou. Oecologia. 144(2):257-267.

Wolda K. 1988. Insect seasonality: why? Annu Rev Ecol Syst. 19:1-18.

Wolf SG, Sydeman WJ, Hipfner JM, Abraham CL, Tershy BR, Croll DA. 2009. Range-wide reproductive consequences of ocean climate variability for the seabird Cassin's auklet. Ecology. 90:742-753.

World Spider Catalog. 2017. World spider catalog. Natural history museum bern. Version 18. [cited 2017 Mar 30]. http://wsc.nmbe.ch

Zar JH. 1998. Biostatistical analysis. Upper Saddle River (NJ): Prentice Hall. 